\title{
EFFECTS OF MANAGEMENT PRACTICES ON WETLAND BIRDS:
}

\section{MARSH WREN}

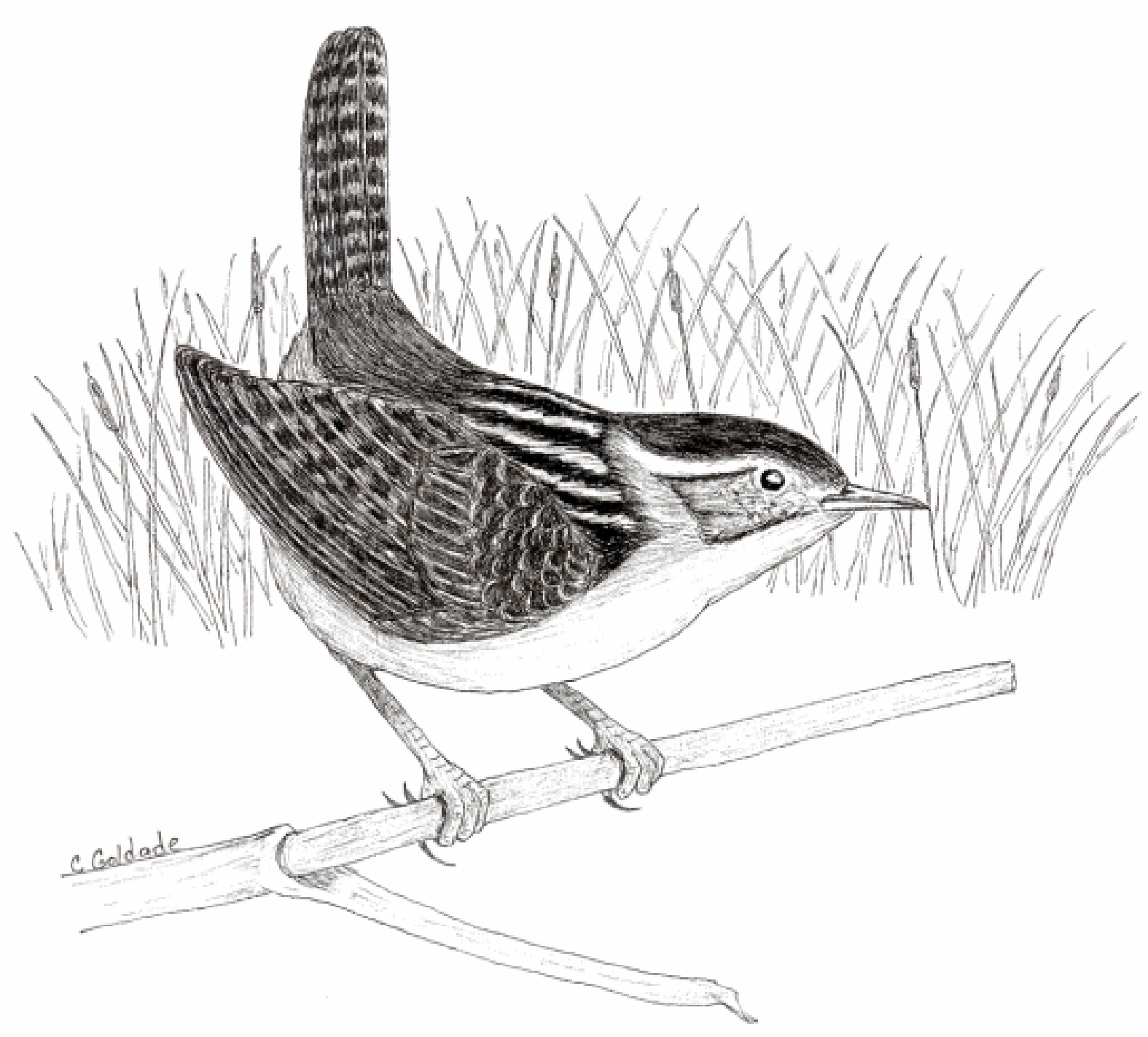

Grasslands Ecosystem Initiative

Northern Prairie Wildlife Research Center

U.S. Geological Survey

Jamestown, North Dakota 58401 
This report is one in a series of literature syntheses on North American wetland birds. The need for these reports was identified by the Prairie Pothole Joint Venture (PPJV), a part of the North American Waterfowl Management Plan. The PPJV adopted a goal to stabilize or increase populations of declining grasslandand wetland-associated wildlife species in the Prairie Pothole Region. To further that objective, it is essential to understand the habitat needs of birds other than waterfowl, and how management practices affect their habitats. The focus of these reports is on management of breeding habitat, particularly in the northern Great Plains.

Suggested citation:

Zimmerman, A. L., J. A. Dechant, D. H. Johnson, C. M. Goldade, J. O. Church, and B. R. Euliss. 2002. Effects of management practices on wetland birds: Marsh Wren. Northern Prairie Wildlife Research Center, Jamestown, ND. 19 pages.

Species for which syntheses are available or are in preparation:

Eared Grebe

American Bittern

Virginia Rail

Sora

Yellow Rail

American Avocet

Willet

Long-billed Curlew
Marbled Godwit

Wilson's Phalarope

Black Tern

Marsh Wren

Sedge Wren

Le Conte's Sparrow

Nelson's Sharp-tailed Sparrow 


\section{EFFECTS OF MANAGEMENT PRACTICES ON WETLAND BIRDS: MARSH WREN}

Amy L. Zimmerman, Jill A. Dechant, Douglas H. Johnson, Christopher M. Goldade, James O. Church, and Betty R. Euliss

Series Coordinator: Douglas H. Johnson Series Assistant Coordinator: Jill A. Dechant

Reviewer: Donald E. Kroodsma

Range Map: Jeff A. Price

Cover Art: Christopher M. Goldade

Funding: Prairie Pothole Joint Venture

U.S. Fish and Wildlife Service U.S. Geological Survey

January 2002 


\section{ORGANIZATION AND FEATURES OF THIS SPECIES ACCOUNT}

Information on the habitat requirements and effects of habitat management on wetland birds were summarized from information in more than 500 published and unpublished papers. A range map is provided to indicate the relative densities of the species in North America, based on Breeding Bird Survey (BBS) data. Although the BBS may not capture the presence of elusive waterbird species, the BBS is a standardized survey and the range maps, in many cases, represent the most consistent information available on species' distributions. Although birds frequently are observed outside the breeding range indicated, the maps are intended to show areas where managers might concentrate their attention. It may be ineffectual to manage habitat at a site for a species that rarely occurs in an area. The species account begins with a brief capsule statement, which provides the fundamental components or keys to management for the species. A section on breeding range outlines the current breeding distribution of the species in North America, including areas that could not be mapped using BBS data. The suitable habitat section describes the breeding habitat and occasionally microhabitat characteristics of the species, especially those habitats that occur in the Great Plains. Details on habitat and microhabitat requirements often provide clues to how a species will respond to a particular management practice. A table near the end of the account complements the section on suitable habitat, and lists the specific habitat characteristics for the species by individual studies. The area requirements section provides details on territory and home range sizes, minimum area requirements, and the effects of patch size, edges, and other landscape and habitat features on abundance and productivity. It may be futile to manage a small block of suitable habitat for a species that has minimum area requirements that are larger than the area being managed. The section on brood parasitism summarizes information on intra- and interspecific parasitism, host responses to parasitism, and factors that influence parasitism, such as nest concealment and host density. The impact of management depends, in part, upon a species' nesting phenology and biology. The section on breeding-season phenology and site fidelity includes details on spring arrival and fall departure for migratory populations in the Great Plains, peak breeding periods, the tendency to renest after nest failure or success, and the propensity to return to a previous breeding site. The duration and timing of breeding varies among regions and years. Species' response to management summarizes the current knowledge and major findings in the literature on the effects of different management practices on the species. The section on management recommendations complements the previous section and summarizes recommendations for habitat management provided in the literature. The literature cited contains references to published and unpublished literature on the management effects and habitat requirements of the species. This section is not meant to be a complete bibliography; a searchable, annotated bibliography of published and unpublished papers dealing with habitat needs of wetland birds and their responses to habitat management is posted at the Web site mentioned below.

This report has been downloaded from the Northern Prairie Wildlife Research Center WorldWide Web site, www.npwrc.usgs.gov/resource/literatr/grasbird/grasbird.htm. Please direct comments and suggestions to Douglas H. Johnson, Northern Prairie Wildlife Research Center, U.S. Geological Survey, 8711 37th Street SE, Jamestown, North Dakota 58401; telephone: 701253-5539; fax: 701-253-5553; e-mail: Douglas_H_Johnson@usgs.gov. 


\section{Marsh Wren}

(Cistothorus palustris)

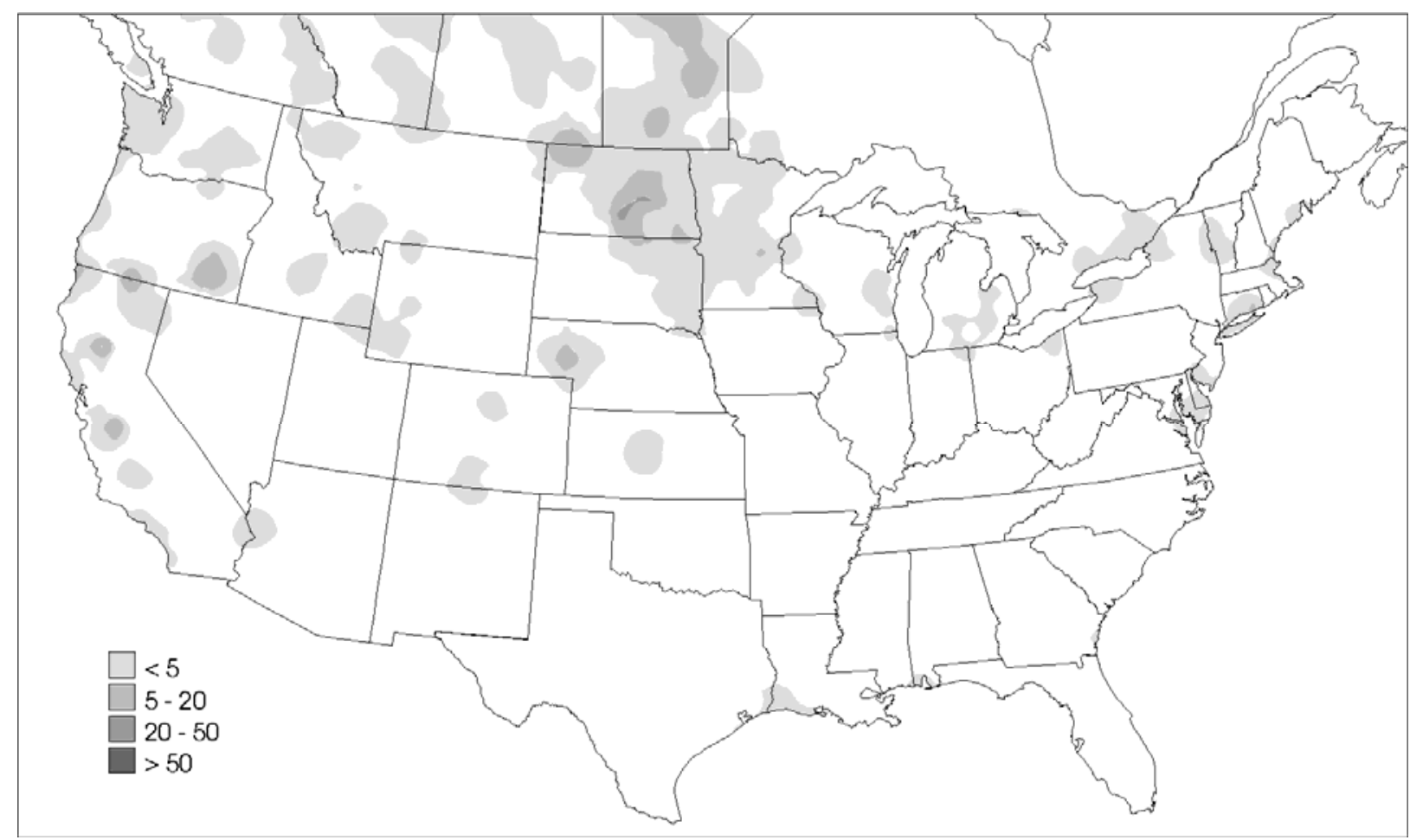

Figure. Breeding distribution of the Marsh Wren in the United States and southern Canada, based on Breeding Bird Survey data, 1985-1991. Scale represents average number of individuals detected per route per year. Map from Price, J., S. Droege, and A. Price. 1995. The summer atlas of North American birds. Academic Press, London, England. 364 pages.

Key to management is maintaining wetlands that have dense stands of emergent vegetation.

\section{Breeding Range:}

Marsh Wrens breed from western British Columbia east through southern Manitoba, Ontario, Quebec, Newfoundland, and New England, south to California, western Arizona, northern New Mexico, central Kansas, and the Gulf Coast, and east through central Missouri, Illinois, Indiana, Ohio, Pennsylvania, and the Atlantic Coast (National Geographic Society 1999). (See figure for the relative densities of Marsh Wrens in the United States and southern Canada, based on Breeding Bird Survey data.)

Suitable habitat:

Marsh Wrens occupy fresh to brackish fen, seasonal, semipermanent, or permanent wetlands with dense, mixed, or monotypic stands of emergent aquatic vegetation such as cattail (Typha spp.), hardstem bulrush (Schoenoplectus acutus), river bulrush (Schoenoplectus fluviatilis), alkali bulrush (Scirpus maritimus), hairy sedge (Carex lacustris), bur-reed (Sparganium eurycarpum), and common reed (Phragmites australis) (Stewart and Kantrud 1965; 
Willson 1967; Burt 1970; Krapu and Duebbert 1974; Stewart 1975; Faanes 1981,1982; Kantrud and Stewart 1984; Burger 1985; Leonard 1986; Gutzwiller and Anderson 1987; Leonard and Picman 1987a,b; Peck and James 1987; Picman et al. 1993; Faanes and Lingle 1995; Prescott et al. 1995; Kroodsma 1997; Naugle 1997). Marsh Wrens are less commonly found in stands of bluejoint (Calamagrostis canadensis) and reed canary grass (Phalaris arundinacea) because these plant types are shorter and have less stem strength than more robust emergents such as cattail (Gutzwiller and Anderson 1987). Marsh Wrens may be found along the banks of slowmoving rivers where emergent vegetation has developed (Johnsgard 1980). In North Dakota, highest densities of Marsh Wrens were found in fen wetlands, followed by semipermanent and seasonal wetlands (Kantrud and Stewart 1984). In Minnesota, Marsh Wrens were found in woody vegetation $<1.5 \mathrm{~m}$ tall or in tame grasses adjacent to wetlands (Niesar 1994). Marsh Wrens also have been observed in restored wetlands (Delphey 1991, Hemesath 1991, Svedarsky 1992, Delphey and Dinsmore 1993, Hemesath and Dinsmore 1993, VanRees-Siewert 1993, Hartman 1994, Schreiber 1994, VanRees-Siewert and Dinsmore 1996, Kroodsma 1997, Schuster 1998).

In seasonal wetlands in eastern South Dakota, the presence of Marsh Wrens was significantly and positively related to the percent of wetland area that was vegetated, dominance of thick-stemmed emergent plants, and presence of untilled land surrounding the wetland (Naugle 1997). In semipermanent wetlands, the presence of Marsh Wrens was positively related to the percent of wetland area that was vegetated and to dominance of thick-stemmed plants. Preliminary data from D. H. Johnson (unpublished data) indicated that in North Dakota and South Dakota, number of breeding pairs of Marsh Wrens was highest in temporary, seasonal, and semipermanent wetlands and was lowest in alkali and permanent wetlands. Number of pairs was higher in restored wetlands than in natural wetlands, and on public land than on private land. Number of breeding pairs increased with increasing amounts of emergent vegetation to a point at which breeding pairs leveled off. Marsh Wrens were more common in wetlands that had semipermanent wetlands within $0.4 \mathrm{~km}$ than in wetlands without semipermanent wetlands nearby.

In Iowa, Marsh Wrens were more likely to be present in natural wetlands than in restored wetlands (Fairbairn and Dinsmore 2001a). The occurrence of Marsh Wrens was positively related to habitat diversity, which was a measure of the evenness of distribution of vegetation zones within a wetland. Density was positively related to the percent of wetland area within a wetland complex that was composed of wet-meadow vegetation, and to the area of emergent vegetation within a complex (Fairbairn and Dinsmore 2001b). Complexes were defined as tracts of land containing from 4 to 15 wetlands ranging from 44 to 144 ha. Occurrence was negatively related to the percent area of a wetland composed of mud flat and percent area composed of open water (Fairbairn and Dinsmore 2001a). Density was negatively related to the ratio of total wetland perimeter to total area of wetlands within a complex (Fairbairn and Dinsmore 2001b). In Wisconsin, density of Marsh Wrens varied according to habitat type (Manci and Rusch (1988). Densities were higher in stands of shallow- and deep-water cattails than in stands of river bulrush and dry cattails. Water depth in shallow-water cattail stands averaged $5 \mathrm{~cm}$ in early June, deep-water cattail stands averaged $29 \mathrm{~cm}$ in early June, dry cattail stands contained no standing water by late June, and river bulrush contained standing water until mid-August. In Alberta, Marsh Wrens were present in wetlands surrounded by newly planted dense nesting 
cover, but were absent from wetlands surrounded by cropland (Prescott et al. 1993). In Manitoba, densities and nest success were higher in a more heterogeneous wetland that supported mixed stands of cattail, common reed, and hardstem bulrush than in a wetland that supported homogeneous stands of cattail (Leonard 1986, Leonard and Picman 1987b). The heterogeneous wetland had taller (29 cm versus $12 \mathrm{~cm}$ ), denser (measurements not given) vegetation and deeper (132 cm versus $92 \mathrm{~cm}$ ) water than the homogeneous wetland.

Marsh Wrens nest over water or damp ground in domed structures anchored to emergent vegetation (Burt 1970, Salt and Salt 1976, Burger 1985, Picman 1986, Peck and James 1987, Kroodsma 1997). In Iowa, 96\% of 227 nests were located in hairy sedge (Burt 1970). Nest locations indicated that Marsh Wrens were not selecting nest sites based on distance to open water or distance to a different vegetative cover type (vegetative cover types included cattail, hairy sedge, bluejoint, bur-reed, sweetflag [Acorus americanus], river bulrush, or prairie cordgrass [Spartina pectinata]). The height above water of 93 nests averaged $32 \mathrm{~cm}$ and ranged from 28 to $112 \mathrm{~cm}$. In North Dakota, 88\% of 25 nests were located in cattail, alkali bulrush, or mixtures of hardstem bulrush and sprangletop (Scolochloa festucacea) (Stewart 1975). Additional nests were located in river bulrush, hardstem bulrush/alkali bulrush, and cattail/sprangletop. The height of 23 nests above water averaged $41 \mathrm{~cm}$ and ranged from 18 to $63.5 \mathrm{~cm}$. The water depth at 19 nests in North Dakota averaged $30 \mathrm{~cm}$ and ranged from 0 to 48 cm (Stewart 1975). In another North Dakota study, the height above water of eight nests averaged $12 \mathrm{~cm}$ (Krapu and Duebbert 1974). In Minnesota, Marsh Wren nests were found in stands of reed canary grass and timothy (Phleum pratense) (Svedarsky 1992). Nests in a restored wetland in Minnesota were found in stands of cattail, bulrush, and common reed (Svedarsky 1992). In Ontario, Marsh Wrens most commonly nested in stands of cattail; elevated nests were most often found in cattail (38\% of 476 nest records) and less often in bulrush, grass, sedge, horsetail (Equisetum sp.), bur-reed, loosestrife (Lythrum), spiraea (Spiraea) or willow (Salix) (Peck and James 1987). The height of 234 nests ranged from 0.2 to $1.5 \mathrm{~m}$ above water. The vegetation supporting nests was usually dead, sometimes living, or a combination of both. Locations of 14 nests ranged from being adjacent to open water to $91 \mathrm{~m}$ from it, and water depths at 31 nests ranged from 5 to $91 \mathrm{~cm}$. In Washington, Marsh Wrens preferred building nests in broad-leaved cattail (Typha latifolia) as long as standing water was present (Verner and Engelsen 1970). As cattail stands dried out, birds abandoned cattail stands to nest in stands of softstem bulrush (Schoenoplectus tabernaemontani) located in standing water. Presence of water could serve as protection against predation or to increase available food sources. Nest height of 81 nests used for breeding (as opposed to unoccupied nests) ranged from 76 to $93 \mathrm{~cm}$ (Verner 1965). Nest height of 548 unoccupied nests ranged from 80 to $95 \mathrm{~cm}$.

In Manitoba, successful nests were surrounded by a significantly greater number of inactive multiple nests than were depredated nests. In Washington, pairing success (defined as the number of mates a male acquired) was positively correlated with total nest sites in a territory (Verner and Engelsen 1970). Male Marsh Wrens build multiple nests within individual territories, but only one is chosen by the female as a nest site; less commonly, new nests are built by females (Provost 1947, Burt 1970, Leonard 1986, Leonard and Picman 1987a, Metz 1991, Kroodsma 1997). Verner (1965) found that males build from 11 to 32 nests. Multiple nests may serve to increase nest success by decreasing the probability that a searching predator will find an active nest (Verner and Engelsen 1970, Leonard and Picman 1987a). Multiple nests also may 
indicate to females the presence of an ample food supply in that males have more time to build multiple nests because of less time needed to forage (Verner and Engelsen 1970). A table near the end of the account lists the specific habitat characteristics for Marsh Wrens by study.

\section{Area requirements:}

One study in Manitoba calculated mean territory sizes for two sites (Leonard and Picman 1986). One site was 6 ha and was dominated by a homogeneous stand of cattail. The mean territory size of 13 males was 0.08 ha. The second site was 4 ha and was a more heterogeneous wetland containing stands of common reed, cattail, and hardstem bulrush. The mean territory size of 16 males was 0.11 ha. In Minnesota, Burns (1982) suggested that Marsh Wren territories were about 0.03 ha. In Washington, territory size varied from 0.005 to 0.34 ha (Verner 1965, Verner and Engelsen 1970). The territory size of Marsh Wrens may be affected by interspecific competition with Yellow-headed Blackbirds (Xanthocephalus xanthocephalus); Leonard and Picman (1986) found that Marsh Wren territories significantly increased in size following the departure of Yellow-headed Blackbirds from early to mid-July. Territories expanded into portions of the wetland with deeper water, which were areas formerly occupied by Yellowheaded Blackbirds. In Iowa, Marsh Wrens were present in all wetland size categories ( $<5$ ha, 520 ha, and $>20$ ha) (Brown and Dinsmore 1986). In Manitoba, Marsh Wrens were present in wetlands of all size categories studied, ranging from $<1$ to 19.3 ha (Daub 1993). In Alberta, Marsh Wrens were present in wetlands ranging from 1 to $>8$ ha (upper size limit not given) (Prescott et al. 1995).

\section{Brood parasitism:}

Brood parasitism by Brown-headed Cowbirds (Molothrus ater) is rare due to the Marsh Wren's characteristic dome-shaped nest and small entrance hole (Picman 1986, Kroodsma 1997). In British Columbia, Picman (1986) found that only one of 1200 nests was parasitized. The nest contained one cold, undamaged cowbird egg and two broken Marsh Wren eggs.

\section{Breeding-season phenology and site fidelity:}

Marsh Wrens arrive on their breeding grounds from April to early May and depart from mid-August through October (Provost 1947, Bent 1964, Stewart 1975, Salt and Salt 1976, Knapton 1979, Johnsgard 1980, Faanes 1981, Leonard 1986, Janssen 1987, Leonard and Picman1987b, Kent and Dinsmore 1996, Kroodsma 1997). The peak breeding season in North Dakota occurs from late May to early August (Stewart 1975). Arrival of females occurs 7-10 d following the arrival of males (Leonard 1986, Leonard and Picman 1987b, Kroodsma 1997). Renesting after the failure of an initial clutch and double-broodedness are common (Verner 1965, Peck and James 1987, Kroodsma 1997). Marsh Wrens use one of their multiple nests for renesting after the destruction of the initial nest. Breeding-site fidelity is low (Leonard 1986, Leonard and Picman 1987b). In Manitoba, 10\% of 41 marked males returned to the same wetland in the second year of the study and 7\% of 28 males returned in the third year (Leonard and Picman 1987b). Only one of 540 marked young returned to the banding area. In Washington, $17 \%$ of 76 adult males returned to the study site the following year (Verner 1971). Of these 13 returning males, mean distance between breeding territories from one year to the next year was $386 \mathrm{~m}$, and five males held the same territory as the previous year. Based on 10 
first-year males, average distance between rearing territories and first breeding territories was $1951 \mathrm{~m}$. Only one of the 10 males had its breeding territory on the same lake where it was reared.

\section{Species’ response to management:}

Little is known concerning the effects of burning, mowing, or grazing on Marsh Wrens. In South Dakota, the presence of Marsh Wrens was negatively related to the intensity of livestock grazing along shorelines of seasonal wetlands (Naugle 1997). In Nebraska, Marsh Wrens were negatively affected by the loss of wetlands by drainage to accommodate expanded agricultural production (Faanes and Lingle 1995). In Iowa, water levels of a 160-ha semipermanent wetland were experimentally manipulated to observe the effects on wetlandnesting species (Weller and Fredrickson 1973). The wetland was reflooded 1 yr after drawdown, after vegetation had germinated and become established. Marsh Wrens were present the year of reflooding and for the next 4 yr. Populations declined 5 and $6 \mathrm{yr}$ after reflooding as the amount of emergent vegetation declined due to inundation by deep water.

Wetlands that have been modified for waterfowl production are commonly used by Marsh Wrens (Brady 1983). In eastern South Dakota, Marsh Wrens were found in dug-brood complexes (system of channels, ponds, and human-created islands constructed on wetlands to provide deep, open water and upland nesting areas for waterfowl) (Brady 1983). Marsh Wrens nested in stands of cattail and bulrush along the shorelines of islands in the dug-brood complexes. Although they were common in both habitats, Marsh Wren densities were higher in unmodified wetlands than in the dug-brood complexes.

Marsh Wrens readily colonize restored wetlands (Hemesath 1991, Svedarsky 1992, Hemesath and Dinsmore 1993, Hartman 1994, Kroodsma 1997). In Iowa, Marsh Wrens have been found to nest in restored wetlands, although densities were higher in natural wetlands (Delphey 1991, Delphey and Dinsmore 1993, Schreiber 1994, Schuster 1998). In other Iowa studies, Marsh Wrens nested in restored wetlands 1-5 yr following restoration; studies did not examine restored wetlands older than 5 yr (Hemesath and Dinsmore 1993, VanRees-Siewert 1993, Schreiber 1994, VanRees-Siewert and Dinsmore 1996). In Indiana, Marsh Wrens occurred in restored wetlands, but not natural wetlands, although the number of natural wetlands sampled was small (Hartman 1994). Restored wetlands often lack wet-meadow zones (VanRees-Siewert 1993, VanRees-Siewert and Dinsmore 1996, Schuster 1998). In Iowa, the absence of wet-meadow zones in restored wetlands may have restricted the use of these wetlands by Marsh Wrens (VanRees-Siewert 1993, VanRees-Siewert and Dinsmore 1996). Hemesath and Dinsmore (1993) found that emergent cover was greater in restored wetlands drained $\leq 30 \mathrm{yr}$ ago than restored wetlands drained $>30 \mathrm{yr}$ ago. Emergent cover is an important habitat requirement for Marsh Wrens and the age of a drained wetland may need to be considered when selecting suitable sites for restoration.

Conversion of wetlands to cranberry (Vaccinium macrocarpon) beds may negatively affect Marsh Wrens because commercial cranberry production requires scraping away native vegetation and soils, ditching, diking, and depositing sand (to provide drainage for the cranberry beds) (Jorgensen and Nauman 1993). Extensive road systems also are built to provide access for maintaining the cranberry beds. In Wisconsin, Marsh Wrens occupied natural habitat within $100 \mathrm{~m}$ of the cranberry beds, but they avoided the cranberry beds themselves. Edges created 
between the cranberry beds and the surrounding native vegetation resulted in higher numbers of Brown-headed Cowbirds in the cranberry beds than in areas near water impoundments.

In North Dakota, glyphosate (N-[phosphonomethyl] glycine) herbicide was aerially applied at a rate of $5.8 \mathrm{~L} /$ ha to reduce cattail in 23 wetlands (Linz et al. 1996). Wetland area was treated at 50\%, 70\%, or $90 \%$ spray coverage. Marsh Wren densities were monitored once immediately prior to treatment and for $2 \mathrm{yr}$ following treatment. Based on seven control wetlands and 16 treated wetlands, densities were significantly higher in control wetlands than in wetlands in all treatment levels combined (2.21 birds/ha versus 0.66 birds/ha, respectively). Based on two wetlands within each treatment, densities were greater in wetlands with $50 \%$ spray coverage than wetlands with $90 \%$ spray coverage (1.04 birds/ha versus 0.26 birds/ha, respectively). Following treatment, densities of Marsh Wrens were positively related to percent cover of live vegetation, negatively related to percent cover of dead vegetation, and not affected by percent open water. In Wisconsin, open water areas were created by eliminating cattails using Amitrol ${ }^{*}$ (1H-1,2,4-triazole-3-ylamine), Radapon or Dowpon (both 2,2-dichloropropionic acid) (Beule 1979). Amitrol and Radapon were applied at rates ranging from 3.85 to $34 \mathrm{~kg} / \mathrm{ha}$. Application rates for Dowpon ranged from 5.6 to10 kg/ha. Marsh Wrens preferred to nest in living, green cattail stands rather than in dead, residual cattail stands.

Marsh Wren mortalities due to collisions with television towers have been reported in Iowa and North Dakota (Avery and Clement 1972, Dinsmore et al. 1987). Casualties occurred during nights with overcast skies. Both adults and juveniles were susceptible (Dinsmore et al. 1987).

\section{Management Recommendations:}

With the exception of VanRees-Siewert (1993) and VanRees-Siewert and Dinsmore (1996), no species-specific management recommendations were found for Marsh Wrens. The management recommendations that follow are based on habitat requirements or apply to the community of wetland bird species as a whole.

Marsh Wrens require dense, robust, vegetatively heterogeneous stands of emergent vegetation (Leonard 1986, Kroodsma 1997). The long-term protection of wetlands can be achieved through conservation easements and purchases of wetland basins (VanRees-Siewert 1993, VanRees-Siewert and Dinsmore 1996). Protecting wetlands $>10$ ha in size will maintain area-dependent species, decrease the proportion of habitat edge, and decrease brood parasitism by Brown-headed Cowbirds (Daub 1993). Protection and restoration of a diversity of wetland types and sizes, and wetlands with a diversity of vegetation zones, is of primary management importance to provide habitat regardless of water conditions in a given year (Fairbairn and Dinsmore 2001b). When selecting wetlands for protection or restoration, the number of other

\footnotetext{
* References to chemical trade names does not imply endorsement of commercial products by the Federal Government.
} 
wetlands in the surrounding landscape and the number of wetlands that support emergent vegetation should be considered as a way to increase density of Marsh Wrens and increase species richness of other waterbird species.

Restoration projects should focus on creating a complex of various-aged wetlands to provide a variety of vegetational stages (Hemesath 1991, Schuster 1998). Restoration of recently ( $<30 \mathrm{yr}$ ago) drained wetlands may promote quick regeneration of wetland vegetation (Hemesath 1991, Hemesath and Dinsmore 1993). In Iowa, emergent cover was greater in restored wetlands that were drained $\leq 30 \mathrm{yr}$ ago than in wetlands drained $>30 \mathrm{yr}$ ago. Restore wetlands that have not been effectively drained, such as those typically used for pasture or hayfields where there is less incentive to completely drain the area. Given that restored wetlands often lack a wet-meadow zone, wet-meadow species may need to be planted in long-since drained wetlands (VanRees-Siewert 1993, VanRees-Siewert and Dinsmore 1996). The absence of wet-meadow zones in restored wetlands may reduce the use of these wetlands by Marsh Wrens.

Grazing of wetlands may be detrimental if the vegetated wetland perimeter that protects nesting habitat and deters nest predators is eliminated (Naugle 1997). In South Dakota, presence of Marsh Wrens increased with percent of wetland area that was vegetated and with amount of untilled land adjacent to wetlands (Naugle 1997). In Alberta, Marsh Wrens appeared to prefer wetlands surrounded by dense nesting cover over wetlands surrounded by cropland (Prescott et al. 1993).

Marsh Wrens have been reported in wetlands of water depths varying from 0 to $132 \mathrm{~cm}$ (Stewart 1975, Leonard and Picman 1987b). Little is known about the effect of fluctuating water levels on Marsh Wrens. Experimental manipulation of a semipermanent wetland involving drawdown and reflooding resulted in Marsh Wrens inhabiting the wetland 1-4 yr after reflooding, and numbers of Marsh Wrens decreasing 5-6 yr after reflooding as water began to inundate vegetation (Weller and Fredrickson 1973). Reduction of cattail coverage may reduce populations of breeding Marsh Wrens (Linz et al. 1996). If cattail control must be conducted, treatments should be staggered in order to maintain various stages of cattail regeneration and growth (Linz et al. 1996). Beule (1979) provided general management recommendations for manipulating cattail growth. 
Table. Marsh Wren habitat characteristics.

\begin{tabular}{|c|c|c|c|}
\hline Author(s) & Location(s) & $\begin{array}{l}\text { Habitat(s) } \\
\text { Studied* }\end{array}$ & Species-specific Habitat Characteristics \\
\hline Beule 1979 & Wisconsin & Wetland & $\begin{array}{l}\text { Preferred nesting in living cattail (Typha spp.) stands } \\
\text { rather than in dead, residual cattail stands }\end{array}$ \\
\hline Brady 1983 & South Dakota & $\begin{array}{l}\text { Wetland, wetland } \\
\text { (modified) }\end{array}$ & $\begin{array}{l}\text { Nested in stands of cattail and bulrush (Scirpus spp.) } \\
\text { along the shorelines of islands and channels in dug- } \\
\text { brood complexes (modified wetlands comprising a } \\
\text { system of channels, ponds, and human-created islands } \\
\text { to provide deep, open water and upland nesting areas } \\
\text { for waterfowl) and in unmodified semipermanent } \\
\text { wetlands; densities were higher on unmodified } \\
\text { wetlands }\end{array}$ \\
\hline Brown and Dinsmore 1986 & Iowa & Wetland & $\begin{array}{l}\text { Occurred in semipermanent and seasonal wetlands } \\
\text { consisting of } 40-60 \% \text { open water and ranging in size } \\
\text { from }<1 \text { ha to }>20 \text { ha }\end{array}$ \\
\hline Burger 1985 & Rangewide & Wetland & Built cup-shaped nests attached to cattail stems \\
\hline Burt 1970 & Iowa & Wetland & $\begin{array}{l}\text { Majority ( } 218 \text { of 227) of nests were located in hairy } \\
\text { sedge (Carex lacustris), four nests were in sweetflag } \\
\text { (Acorus americanus), two in tussock sedge (Carex } \\
\text { tuckermanni), two in river bulrush (Schoenoplectus } \\
\text { fluviatilis), and one in bur-reed (Sparganium } \\
\text { eurycarpum); height above water of } 93 \text { nests averaged } \\
32 \mathrm{~cm} \text { and ranged from } 18 \text { to } 112 \mathrm{~cm} \text {; } 35 \% \text { of } 179 \text { nests } \\
\text { were located within } 6 \mathrm{~m} \text { of open water; only } 36 \% \text { of } \\
247 \text { nests were located within } 6 \text { m of an edge between } \\
\text { two different vegetative cover types }\end{array}$ \\
\hline
\end{tabular}




\begin{tabular}{|c|c|c|c|}
\hline Daub 1993 & Manitoba & Wetland & $\begin{array}{l}\text { Occurred in wetlands ranging in size from } 0.1 \text { to } 19.3 \\
\text { ha }\end{array}$ \\
\hline $\begin{array}{l}\text { Delphey 1991, } \\
\text { Delphey and Dinsmore } 1993\end{array}$ & Iowa & $\begin{array}{l}\text { Wetland, wetland } \\
\text { (restored) }\end{array}$ & $\begin{array}{l}\text { Densities were higher in natural wetlands than in } \\
\text { restored wetlands, although nesting occurred in both } \\
\text { natural and restored wetlands }\end{array}$ \\
\hline Faanes 1982 & North Dakota & $\begin{array}{l}\text { Cropland, mixed- } \\
\text { grass, wetland, } \\
\text { woodland }\end{array}$ & $\begin{array}{l}\text { Occurred in dense growths of cattail and hardstem } \\
\text { bulrush (Schoenoplectus acutus) on the periphery of } \\
\text { semipermanent and permanent wetlands }\end{array}$ \\
\hline Faanes and Lingle 1995 & Nebraska & $\begin{array}{l}\text { River channel } \\
\text { island, wetland }\end{array}$ & $\begin{array}{l}\text { Nesting densities were highest in prairie wetlands, } \\
\text { followed by river channel islands }\end{array}$ \\
\hline $\begin{array}{l}\text { Fairbairn and Dinsmore } \\
2001 a, b\end{array}$ & Iowa & Wetland complex & $\begin{array}{l}\text { More likely to be present in natural wetlands than in } \\
\text { restored wetlands; occurrence was positively related to } \\
\text { habitat diversity, which was a measure of the evenness } \\
\text { of distribution of vegetation zones within a wetland, } \\
\text { and negatively related to the percent area of a wetland } \\
\text { composed of mud flat and percent area composed of } \\
\text { open water; density was positively related to the } \\
\text { percent of wetland area within a wetland complex that } \\
\text { was composed of wet-meadow vegetation and to the } \\
\text { area of emergent vegetation within a complex, and } \\
\text { negatively related to the ratio of total wetland perimeter } \\
\text { to total area of wetlands within a complex; complexes } \\
\text { were defined as tracts of land containing from } 4 \text { to } 15 \\
\text { wetlands ranging from } 44 \text { to } 144 \text { ha }\end{array}$ \\
\hline Hartman 1994 & Indiana & $\begin{array}{l}\text { Wetland, wetland } \\
\text { (restored) }\end{array}$ & $\begin{array}{l}\text { Occurred in restored wetlands but not in natural } \\
\text { wetlands }\end{array}$ \\
\hline
\end{tabular}




\begin{tabular}{|c|c|c|c|}
\hline $\begin{array}{l}\text { Hemesath 1991, } \\
\text { Hemesath and Dinsmore } 1993\end{array}$ & Iowa & Wetland (restored) & Nested in 1- to 3-yr old restored wetlands \\
\hline Johnsgard 1980 & Nebraska & Wetland & $\begin{array}{l}\text { Occurred in freshwater wetlands with extensive } \\
\text { emergent vegetation and along banks of slow-moving } \\
\text { rivers with developing emergent vegetation }\end{array}$ \\
\hline Kantrud and Stewart 1984 & North Dakota & Wetland & $\begin{array}{l}\text { Densities were highest in fens, followed by } \\
\text { semipermanent and seasonal wetlands }\end{array}$ \\
\hline Krapu and Duebbert 1974 & North Dakota & Wetland & $\begin{array}{l}\text { Nested in dense cattail stands; mean water depth at } \\
\text { eight nests was } 29 \mathrm{~cm} \text {; height above water of eight } \\
\text { nests averaged } 12 \mathrm{~cm}\end{array}$ \\
\hline Leonard 1986 & Manitoba & Wetland & $\begin{array}{l}\text { Water depth and maximum vegetation height at } 26 \\
\text { nests in a vegetatively homogeneous wetland averaged } \\
20.5 \mathrm{~cm} \text { and } 134.5 \mathrm{~cm} \text {, respectively; water depth and } \\
\text { maximum vegetation height at } 33 \text { nests in a } \\
\text { vegetatively heterogeneous wetland averaged } 20.6 \mathrm{~cm} \\
\text { and } 162 \mathrm{~cm} \text {, respectively }\end{array}$ \\
\hline Leonard and Picman 1987b & Manitoba & Wetland & $\begin{array}{l}\text { Density and nest success were higher in a more } \\
\text { heterogeneous wetland that consisted of mixed stands } \\
\text { of cattail, common reed (Phragmites australis), and } \\
\text { hardstem bulrush than in a wetland consisting of a } \\
\text { homogeneous stand of cattail; nest success was higher } \\
\text { in the more heterogeneous wetland, probably because it } \\
\text { had taller ( } 29 \mathrm{~cm} \text { versus } 12 \mathrm{~cm}) \text {, denser vegetation and } \\
\text { deeper ( } 132 \mathrm{~cm} \text { versus } 92 \mathrm{~cm} \text { ) water than the } \\
\text { homogeneous wetland }\end{array}$ \\
\hline Linz et al. 1996 & North Dakota & Wetland & $\begin{array}{l}\text { Following glyphosate herbicide treatment to control } \\
\text { cattail, densities of Marsh Wrens were positively }\end{array}$ \\
\hline
\end{tabular}




\begin{tabular}{|c|c|c|c|}
\hline & & & $\begin{array}{l}\text { related to percent cover of live vegetation and } \\
\text { negatively related to percent cover of dead vegetation }\end{array}$ \\
\hline Manci and Rusch 1988 & Wisconsin & Wetland & $\begin{array}{l}\text { Densities were highest in shallow- and deep-water } \\
\text { cattail stands, followed by river bulrush and dry cattail } \\
\text { stands; water depth in shallow-water cattail stands } \\
\text { averaged } 5 \mathrm{~cm} \text { in early June (sample sizes not given), } \\
\text { deep-water cattail stands averaged } 29 \mathrm{~cm} \text { in early June, } \\
\text { dry cattail stands contained no standing water by late } \\
\text { June, and river bulrush contained standing water until } \\
\text { mid-August }\end{array}$ \\
\hline Naugle 1997 & South Dakota & $\begin{array}{l}\text { Conservation } \\
\text { Reserve Program } \\
\text { (idle seeded-native, } \\
\text { idle tame), } \\
\text { cropland, idle } \\
\text { mixed-grass, idle } \\
\text { tallgrass, idle tame, } \\
\text { mixed-grass } \\
\text { pasture, tallgrass } \\
\text { pasture, tame } \\
\text { pasture, wetland }\end{array}$ & $\begin{array}{l}\text { Presence in seasonal wetlands was significantly and } \\
\text { positively related to the percent of wetland area that } \\
\text { was vegetated, dominance of thick-stemmed emergent } \\
\text { plants, and presence of untilled land adjacent to } \\
\text { wetlands; presence was negatively related to the } \\
\text { intensity of grazing along shorelines of seasonal } \\
\text { wetlands; presence in semipermanent wetlands was } \\
\text { positively related to the percent of the wetland that was } \\
\text { vegetated and dominance of thick-stemmed plants }\end{array}$ \\
\hline Niesar 1994 & Minnesota & $\begin{array}{l}\text { Waterfowl } \\
\text { Production Area } \\
\text { (idle mixed-grass, } \\
\text { idle tame), wetland, } \\
\text { woodland }\end{array}$ & $\begin{array}{l}\text { Occurred in wetlands and in brush or tame grasses } \\
\text { adjacent to wetlands }\end{array}$ \\
\hline Peck and James 1987 & Ontario & Wetland & $\begin{array}{l}\text { Nested adjacent to or } \leq 91 \mathrm{~m} \text { from open water; elevated } \\
\text { nests most often were found in cattail ( } 179 \text { records) and }\end{array}$ \\
\hline
\end{tabular}




\begin{tabular}{|c|c|c|c|}
\hline & & & $\begin{array}{l}\text { less often in bulrush, grass, sedge, horsetail (Equisetum } \\
\text { sp.), bur-reed, loosestrife (Lythrum), spiraea (Spiraea) } \\
\text { or willow (Salix); vegetation supporting nests usually } \\
\text { was dead, sometimes living, or a combination of both; } \\
\text { water depths at } 31 \text { nests ranged from } 5 \text { to } 91 \mathrm{~cm} \text {; height } \\
\text { of } 234 \text { nests above water ranged from } 0.2 \text { to } 1.5 \mathrm{~m}\end{array}$ \\
\hline Picman et al. 1993 & Ontario & Wetland & $\begin{array}{l}\text { Nested in a wetland with dense, uniform stands of } \\
\text { cattails and water depth ranging from } 0 \text { to } 120 \mathrm{~cm}\end{array}$ \\
\hline Prescott et al. 1993 & Alberta & $\begin{array}{l}\text { Cropland, dense } \\
\text { nesting cover (idle } \\
\text { seeded-native), } \\
\text { mixed-grass } \\
\text { pasture, tame } \\
\text { pasture, wetland, } \\
\text { wetland (restored) }\end{array}$ & $\begin{array}{l}\text { Occurred in wetlands surrounded by newly ( }<1 \mathrm{yr} \text { ) } \\
\text { planted dense nesting cover, but were absent from } \\
\text { wetlands surrounded by cropland }\end{array}$ \\
\hline Prescott et al. 1995 & Alberta & Wetland & $\begin{array}{l}\text { Occurred in large ( }>8 \mathrm{ha} \text { ) and medium (1-8 ha) sized } \\
\text { fresh wetlands; absent from saline wetlands }\end{array}$ \\
\hline Salt and Salt 1976 & Alberta & Wetland & $\begin{array}{l}\text { Nested in cattail and rushes (Juncus spp.); nests were } \\
0.3 \text { to } 1.2 \mathrm{~m} \text { above water }\end{array}$ \\
\hline Schreiber 1994 & Iowa & $\begin{array}{l}\text { Wetland, wetland } \\
\text { (restored) }\end{array}$ & $\begin{array}{l}\text { Frequency of occurrence and nest density were greater } \\
\text { in natural wetlands than restored wetlands; Marsh } \\
\text { Wrens first appeared and nested on 2-yr-old restored } \\
\text { wetlands, and also nested on 4- and 5-yr-old restored } \\
\text { wetlands }\end{array}$ \\
\hline Schuster 1998 & Iowa & $\begin{array}{l}\text { Wetland, wetland } \\
\text { (restored) }\end{array}$ & $\begin{array}{l}\text { Frequency of occurrence and nest density were greater } \\
\text { in natural wetlands than restored wetlands in one year, } \\
\text { but were similar in natural and restored wetlands the }\end{array}$ \\
\hline
\end{tabular}




\begin{tabular}{|c|c|c|c|}
\hline & & & next year \\
\hline Stewart 1975 & North Dakota & $\begin{array}{l}\text { Wetland, wetland } \\
\text { (restored) }\end{array}$ & $\begin{array}{l}\text { Nests were located in cattail, alkali bulrush (Scirpus } \\
\text { maritimus), and stands of hardstem bulrush and } \\
\text { sprangletop (Scolochloa festucacea); height of } 23 \text { nests } \\
\text { above water averaged } 41 \mathrm{~cm} \text { and ranged from } 18 \text { to } \\
63.5 \mathrm{~cm} \text {; water depth at } 19 \text { nests averaged } 30 \mathrm{~cm} \text { and } \\
\text { ranged from } 0 \text { to } 48 \mathrm{~cm}\end{array}$ \\
\hline Stewart and Kantrud 1965 & North Dakota & Wetland & $\begin{array}{l}\text { Densities were highest in fresh to brackish } \\
\text { semipermanent wetlands with closed stands of } \\
\text { emergent cover }\end{array}$ \\
\hline Svedarsky 1992 & Minnesota & Wetland (restored) & $\begin{array}{l}\text { Nested in a stand of reed canary grass (Phalaris } \\
\text { arundinacea) and timothy (Phleum pratense); nests in } \\
\text { the restored wetland in Minnesota were found in stands } \\
\text { of cattail, bulrush, and common reed }\end{array}$ \\
\hline $\begin{array}{l}\text { VanRees-Siewert 1993, } \\
\text { VanRees-Siewert and } \\
\text { Dinsmore } 1996\end{array}$ & Iowa & Wetland & Nested in 3- and 4-yr-old restored wetlands \\
\hline Verner 1965 & Washington & Wetland & $\begin{array}{l}\text { Nest height of } 548 \text { dummy nests ranged from } 80 \text { to } 95 \\
\text { cm; nest height of } 81 \text { breeding nests ranged from } 76 \text { to } \\
\text { 93; based on } 26 \text { males, a range of } 11 \text { to } 32 \text { nests were } \\
\text { completed per male }\end{array}$ \\
\hline Verner and Engelsen 1970 & Washington & Wetland & $\begin{array}{l}\text { Preferred to nest in broad-leaved cattail (Typha } \\
\text { latifolia) as long as standing water was present, but as } \\
\text { cattail stands dried out, birds abandoned cattail stands } \\
\text { to nest in stands of softstem bulrush (Schoenoplectus } \\
\text { tabernaemontani) located in standing water; pairing } \\
\text { success was negatively correlated with percent bulrush }\end{array}$ \\
\hline
\end{tabular}




\begin{tabular}{|l|l|l|}
\hline & & \\
& & $\begin{array}{l}\text { in a territory and positively correlated with total nest } \\
\text { sites in a territory; area of pure cattail, area of pure } \\
\text { bulrush, area of mixed cattail and bulrush, total area, } \\
\text { percent pure cattail, and percent mixed cattail and } \\
\text { bulrush were not correlated with pairing success }\end{array}$ \\
\hline
\end{tabular}

*In an effort to standardize terminology among studies, various descriptors were used to denote the management or type of habitat. "Idle" used as a modifier (e.g., idle tallgrass) denotes undisturbed or unmanaged (e.g., not burned, mowed, or grazed) areas. "Idle" by itself denotes unmanaged areas in which the plant species were not mentioned. Examples of "idle" habitats include weedy or fallow areas (e.g., oldfields), fencerows, grassed waterways, terraces, ditches, and road rights-of-way. "Tame" denotes introduced plant species (e.g., smooth brome [Bromus inermis]) that are not native to North American prairies. "Hayland" refers to any habitat that was mowed, regardless of whether the resulting cut vegetation was removed. "Burned" includes habitats that were burned intentionally or accidentally or those burned by natural forces (e.g., lightning). In situations where there are two or more descriptors (e.g., idle tame hayland), the first descriptor modifies the following descriptors. For example, idle tame hayland is habitat that is usually mowed annually but happened to be undisturbed during the year of the study. 


\section{LITERATURE CITED}

Avery, M., and T. Clement. 1972. Bird mortality at four towers in eastern North Dakota. Prairie Naturalist 4:87-95.

Bent, A. C. 1964. Life histories of North American nuthatches, wrens, thrashers, and their allies. Dover Publications, Inc., New York, New York. 475 pages.

Beule, J. D. 1979. Control and management of cattails in southeastern Wisconsin wetlands. Wisconsin Department of Natural Resources, Madison, Wisconsin. Technical Bulletin No. 112. 39 pages.

Brady, E. N. 1983. Birds on modified wetlands in eastern South Dakota. M.S. thesis. South Dakota State University, Brookings, South Dakota. 39 pages.

Brown, M., and J. J. Dinsmore. 1986. Implications of marsh size and isolation for marsh bird management. Journal of Wildlife Management 50:392-397.

Burger, J. 1985. Habitat selection in temperate marsh-nesting birds. Pages 253-281 in M. L. Cody, editor. Habitat selection in birds. Academic Press, Inc., Orlando, Florida.

Burns, J. T. 1982. Nests, territories, and reproduction of Sedge Wrens (Cistothorus platensis). Wilson Bulletin 94:338-349.

Burt, D. E. 1970. Habitat selection and species interactions of some marsh passerines. M.S. thesis. Iowa State University, Ames, Iowa. 75 pages.

Daub, B. C. 1993. Effects of marsh area and characteristics on avian diversity and nesting success. M.S. thesis. University of Michigan, Ann Arbor, Michigan. 37 pages.

Delphey, P. J. 1991. A comparison of the bird and aquatic macroinvertebrate communities between restored and 'natural' Iowa prairie wetlands. M.S. thesis. Iowa State University, Ames, Iowa. 85 pages.

Delphey, P. J., and J. J. Dinsmore. 1993. Breeding bird communities of recently restored and natural prairie potholes. Wetlands 13:200-206.

Dinsmore, S., E. Munson, J. J. Dinsmore, and G. M. Nelson. 1987. Two television tower kills in Iowa. Iowa Bird Life 57:5-8.

Faanes, C. A. 1981. Birds of the St. Croix River Valley: Minnesota and Wisconsin. U.S. Fish and Wildlife Service, Washington, D.C. North American Fauna 73. 196 pages. 
Faanes, C. A. 1982. Avian use of Sheyenne Lake and associated habitats in central North Dakota. U.S. Fish and Wildlife Service, Resource Publication 144. 24 pages.

Faanes, C. A., and G. R. Lingle. 1995. Breeding birds of the Platte River Valley of Nebraska. Jamestown, ND: Northern Prairie Wildlife Research Center home page. http://www.npwrc.usgs.gov/resource/distr/birds/platte/platte.htm (Version 02SEP99).

Fairbairn, S. E, and J. J. Dinsmore. 2001a. Factors associated with occurrence and density of wetland birds in the Prairie Pothole Region of Iowa. Journal of the Iowa Academy of Science 108:8-14.

Fairbairn, S. E., and J. J. Dinsmore. 2001b. Local and landscape-level influences on wetland bird communities of the prairie pothole region of Iowa, USA. Wetlands 21:41-47.

Gutzwiller, K. J., and S. H. Anderson. 1987. Habitat suitability index models: Marsh Wren. National Ecology Research Center, U.S. Fish and Wildlife Service, U.S. Department of the Interior, Washington, D.C. 13 pages.

Hartman, M. R. 1994. Avian use of restored and natural wetlands in northcentral Indiana. M.S. thesis. Purdue University, West Lafayette, Indiana. 98 pages.

Hemesath, L. M. 1991. Species richness and nest productivity of marsh birds on restored prairie potholes in northern Iowa. M.S. thesis. Iowa State University, Ames, Iowa. 87 pages.

Hemesath, L. M., and J. J. Dinsmore. 1993. Factors affecting bird colonization of restored wetlands. Prairie Naturalist 25:1-11.

Janssen, R. B. 1987. Birds in Minnesota. University of Minnesota Press, Minneapolis, Minnesota. 352 pages.

Johnsgard, P. A. 1980. A preliminary list of the birds of Nebraska and adjacent Plains states. University of Nebraska, Lincoln, Nebraska. 156 pages.

Jorgensen, E. E., and L. E. Nauman. 1993. Bird distribution in wetlands associated with commercial cranberry production. Passenger Pigeon 55:289-298.

Kantrud, H. A., and R. E. Stewart. 1984. Ecological distribution and crude density of breeding birds on prairie wetlands. Journal of Wildlife Management 48:426-437.

Kent, T. H., and J. J. Dinsmore. 1996. Birds in Iowa. Published by the authors, Iowa City and Ames, Iowa. 391 pages.

Knapton, R. W. 1979. Birds of the Gainsborough-Lyleton region. Saskatchewan Natural History Society Special Publication 10. 72 pages. 
Krapu, G. L., and H. F. Duebbert. 1974. A biological survey of Kraft Slough. Prairie Naturalist 6:33-55.

Kroodsma, D. E. 1997. Marsh Wren (Cistothorus palustris). A. Poole and F. Gill, editors. The birds of North America, No. 308. The Academy of Natural Sciences, Philadelphia, Pennsylvania; The American Ornithologists’ Union, Washington, D.C.

Leonard, M. L. 1986. Female choice and the evolution of polygyny in the Marsh Wren (Cistothorus palustris). Ph.D. dissertation. University of Ottawa, Ottawa, Ontario. 177 pages.

Leonard, M. L., and J. Picman. 1986. Why are nesting Marsh Wrens and Yellow-headed Blackbirds spatially segregated? Auk 103:135-140.

Leonard, M. L., and J. Picman. 1987a. The adaptive significance of multiple nest building by male Marsh Wrens. Animal Behaviour 35:271-277.

Leonard, M. L., and J. Picman. 1987b. Nesting mortality and habitat selection by Marsh Wrens. Auk 104:491-495.

Linz, G. M., D. C. Blixt, D. L. Bergman, and W. J. Bleier. 1996. Responses of Red-winged Blackbirds, Yellow-headed Blackbirds and Marsh Wrens to glyphosate-induced alterations in cattail density. Journal of Field Ornithology 67:167-176.

Manci, K. M., and D. H. Rusch. 1988. Indices to distribution and abundance of some inconspicuous waterbirds on Horicon Marsh. Journal of Field Ornithology 59:67-75.

Metz, K. J. 1991. The enigma of multiple nest building by male Marsh Wrens. Auk 108:170173.

National Geographic Society. 1999. Field guide to the birds of North America, third edition. National Geographic Society, Washington, D.C. 480 pages.

Naugle, D. E. 1997. Habitat area requirements of prairie wetland birds in eastern South Dakota. Ph.D. dissertation. South Dakota State University, Brookings, South Dakota. 85 pages.

Niesar, S. L. 1994. Vertebrated richness of Waterfowl Production Areas in the Prairie Pothole region of Minnesota. M.S. thesis. South Dakota State University, Brookings, South Dakota. 104 pages.

Peck, G. K., and R. D. James. 1987. Breeding birds of Ontario, volume 2: passerines. Royal Ontario Museum Publications in Life Sciences. Royal Ontario Museum, Toronto, Ontario. 387 pages. 
Picman, J. 1986. Attempted nest parasitism of the Marsh Wren by a Brown-headed Cowbird. Condor 88:381-382.

Picman, J., M. L. Milks, and M. Leptich. 1993. Patterns of predation on passerine nests in marshes: effects of water depth and distance from edge. Auk 110:89-94.

Prescott, D. R. C., R. Arbuckle, B. Goddard, and A. J. Murphy. 1993. Methods for the monitoring and assessment of avian communities on NAWMP landscapes in Alberta, and 1993 results. NAWMP-007. Alberta NAWMP Centre, Edmonton, Alberta. 48 pages.

Prescott, D. R. C., A. J. Murphy, and E. Ewaschuk. 1995. An avian community approach to determining biodiversity values of NAWMP habitats in the aspen parkland of Alberta. NAWMP-012. Alberta NAWMP Centre, Edmonton, Alberta. 58 pages.

Provost, M. W. 1947. Nesting of birds in the marshes of northwest Iowa. American Midland Naturalist 38:485-503.

Salt, W. R., and J. R. Salt. 1976. The birds of Alberta. Hurtig Publishers, Edmonton, Alberta. 498 pages.

Schreiber, J. A. 1994. Structure of breeding-bird communities on natural and restored Iowa wetlands. M.S. thesis. Iowa State University, Ames, Iowa. 85 pages.

Schuster, J. E. 1998. Avian community composition and diversity in natural and restored central Iowa wetlands. M.S. thesis. Iowa State University, Ames, Iowa. 74 pages.

Stewart, R. E. 1975. Breeding birds of North Dakota. Tri-College Center for Environmental Studies, Fargo, North Dakota. 295 pages.

Stewart, R. E., and H. A. Kantrud. 1965. Ecological studies of waterfowl populations in the prairie potholes of North Dakota. U.S. Fish and Wildlife Service, Bureau of Sport Fisheries and Wildlife. 1965 Progress Report. 14 pages.

Svedarsky, W. D. 1992. Biological inventory of a multi-purpose flood control impoundment in northwestern Minnesota and potentials for nongame and game bird management. Final Report. Northwest Agricultural Experiment Station, University of Minnesota, Crookston, Minnesota. 115 pages.

VanRees-Siewert, K. L. 1993. The influence of wetland age on bird and aquatic macroinvertebrate use of restored Iowa wetlands. M.S. thesis. Iowa State University, Ames, Iowa. 96 pages. 
VanRees-Siewert, K. L., and J. J. Dinsmore. 1996. Influence of wetland age on bird use of restored wetlands in Iowa. Wetlands 16:577-582.

Verner, J. 1965. Breeding biology of the Long-billed Marsh Wren. Condor 67:6-30.

Verner, J. 1971. Survival and dispersal of male Long-billed Marsh Wrens. Bird-Banding 42:92-98.

Verner, J., and G. H. Engelsen. 1970. Territories, multiple nest building, and polygyny in the Long-billed Marsh Wren. Auk 87:557-567.

Weller, M. W., and L. H. Fredrickson. 1973. Avian ecology of a managed glacial marsh. Living Bird 12:269-291.

Willson, M. F. 1967. Notes on the interspecific behavioral relationships of marsh-nesting passerines. Auk 84:118-120. 